Michal SMOLINSKI

Tomasz PERKOWSKI

Arkadiusz MYSTKOWSKI

Egidijus DRAGAŠIUS

Darius EIDUKYNAS

Rafal P. JASTRZEBSKI

\title{
AMB FLYWHEEL INTEGRATION WITH PHOTOVOLTAIC SYSTEM FOR HOUSEHOLD PURPOSE - MODELLING AND ANALYSIS
}

\section{INTEGRACJA ŁOŻYSKOWANEGO MAGNETYCZNIE ZASOBNIKA ENERGII KINETYCZNEJ Z UKŁADEM PANELI FOTOWOLTAICZNYCH DLA ZASTOSOWAŃ W GOSPODARSTWACH DOMOWYCH - MODELOWANIE I ANALIZA}

\begin{abstract}
This paper presents the design and investigation of a photovoltaic-flywheel system for household purposes. The main goal of this work is the electrical and mechanical integration of the electromechanical high speed kinetic energy storage as UPS (Uninterruptible Power Supply) with photovoltaic solar system. The paper contains calculation and division of photovoltaic panels system according to its integration with active magnetic bearing (AMB) flywheel and external electric grid. The photovoltaic solar installation costs as well as its size were considered. The composite shell AMB flywheel prototype configuration design (using CAD-software) and two different material variants are investigated and presented. In particularly, the structural composite shell stress calculations of two different materials vs rotational speed are performed using a direct coupling of SolidWorks and Matlab ${ }^{\circledR}$ software. The analytical calculations of PV-flywheel system are provided in order to choose optimal type of photovoltaic panels according to motor/generator flywheel and household energy system requirements. All elements of PV-flywheel system as transducers, bridges, wiring diagrams, etc., are optimized using Simscape tools. Finally, short- and long-time simulations results of $P V-A M B-f l y w h e e l$ system and initial experimental results are presented and discussed.
\end{abstract}

Keywords: photovoltaic solar system, photovoltaic panels, AMB flywheel, kinetic energy storage, UPS device, motor/generator, composite materials.

\begin{abstract}
$W$ artykule przedstawiono wstępne badania zintegrowanego układu paneli fotowoltaicznych z łożyskowanym magnetycznie zasobnikiem energii kinetycznej. Głównym celem pracy jest próba integracji elementów elektrycznych i mechanicznych wysokoobrotowego elektromechanicznego magazynu energii kinetycznej jako urzadzenia UPS z uktadem paneli fotowoltaicznych. W szczególności przeprowadzono obliczenia najważniejszych parametrów elektrycznych łożyskowanego magnetycznie zasobnika energii połaczonego z uktadem paneli fotowoltaicznych celem jego integracji z trakcja sieci elektrycznej niskiego napięcia. Wykorzystując pakiety oprogramowania: CAD, SolidWorks i Matlab, wykonano badania symulacyjne wskaźników wytrzymałości koła zamachowego zasobnika energii kinetycznej w szerokim zakresie prędkości obrotowej dla dwóch różnych typów materiałów kompozytowych. Następnie, wykorzystując między innymi narzędzia Simscape, przeprowadzono optymalizację elementów systemu celem dopasowania jego głównych parametrów do wymagań stawianym domowym instalacjom fotowoltaicznym z akumulatorami energii elektrycznej. Wyniki badań symulacyjnych, przeprowadzone w cyklach krótko-i dtugo-czasowych, uktadu paneli fotowoltaicznych zintegrowanych z elektromechanicznym akumulatorem energii potwierdzity wstępne obliczenia i zatożenia.
\end{abstract}

Stowa kluczowe: instalacja fotowoltaiczna, panele fotowoltaiczne, tożyskowany magnetycznie zasobnik energii kinetycznej, magazyn energii kinetycznej, urzadzenie UPS, silnik/pradnica, materiaty kompozytowe.

\section{Introduction}

A UPS device is an uninterruptable power supply, the main objective of which is to maintain the operation of other devices in the event of a power supply failure. These devices belong to an important group and may be useful in many fields. Small-scale UPS devices are mostly used in hospitals to maintain the operation of medical equipment in case of a power blackout; many of these devices are also used to maintain power in server computers and home appliances. Energy storage devices support electric grids where uninterruptible power supply is needed. Main advantages of energy storage systems and applications in electrical power systems have been described in $[19,22]$.

Photovoltaic (PV) panels (solar cells) make it possible to convert solar energy into electric energy, which can supply electric devices. These panels are useful in many fields of science and applications of residential distribution grids as well as in PV-thermal domestic systems $[21,24]$. Solar cells can be used to power many domestic 
devices, for example in the field of home appliances, where charge accumulators and conventional UPS are suitable for further supply [3]. Due to the cycle of day and night, as well as changes in weather conditions, the panels are not able to fully supply devices designed to work continuously.

Nowadays, flywheels and batteries are viable energy storage technologies, which become practical solutions for applications where energy has to be saved for further use at any time. An overview of distributed energy storage systems for applications in future smart grids is presented in work [10]. Due to significant improvements in materials and mechatronics technology, the flywheels find the most promising applications for energy storage and become an alternative to batteries in UPS systems $[4,5]$. In comparison to batteries, the flywheel has higher energy density (up to $100 \mathrm{Wh} / \mathrm{kg}$ ), higher maximum peak power (over $10 \mathrm{~kW} / \mathrm{kg}$ ) and higher efficiency. A review of flywheelbased energy storage systems has been given in [17]. The active magnetic bearing (AMB) flywheel prototype design and control approach have been given by the author in $[11,12]$. Major advantages of AMB flywheels result from modern technologies of composite materials with high tensile strength, which allow for high rotational speeds and high energy density $[2,7]$. Also, flywheel design needs efficient solutions in electric motor/generator technologies using permanent magnet solutions and advanced control systems $[8,13,23]$.

In a context where renewable energy from solar panels has low predictability and strong variability, integration into power systems may cause instabilities of these grids [14, 21]. Moreover, there are other, similar aspects that make integration of solar panels and electromechanical flywheel technology a challenge [9]. Therefore, this system always requires initial modelling and calculations according to the specific power system integration. In particular, the main advantage of UPS-flywheel integration with a photovoltaic solar system is that it provides efficient production control as well as good power management with energy saving and smooth power grids. Flywheels can address solar frequency variability and offer fast power response with high ramp rates and amplitude $[1,8]$.

If these renewable energy technologies are synthesized, it will be possible to charge accumulators and supply households by using both photovoltaic panels and solar panels' energy [6]. In the case of adverse weather conditions, accumulators should also be charged from the electric grid to provide continuous power supply. Integrated energy storages have huge potential because they reduce usage of the power grid by devices which require continuous power supply, and they are also irreplaceable for devices sensitive to voltage spikes.

\section{Photovoltaic system}

The application of photovoltaic solar panels as alternative sources of energy makes a device independent from the power grid. Solar cells can convert solar energy directly and supply devices with electric power or store it (e.g. in the accumulator as flywheel) for later use or for sale. Unfortunately, solar cells are very vulnerable to varying weather conditions. Nowadays, the market offers many standalone photovoltaic panels and whole photovoltaic systems. In this paper, the system design will concentrate on offered solutions that contain only photovoltaic panels without any additional components.

The selection of a photovoltaic installation should be made in a few steps. The first step is to determine the type of the installation. The most optimal solution is a hybrid installation, which is a combination of an in-grid installation (a photovoltaic solar system connected to power grid) and fixed installation (which is attached to the defined surface at a certain angle).

The second step involves determination of the quantity of solar panels. The chosen method uses nominal power of photovoltaic panels and includes losses accounted for by corresponding coefficients:

$$
E_{a}=P_{P V} \cdot W_{1} \cdot W_{2} \cdot W_{3} \cdot S
$$

where: $S$ - losses, $W_{1}$ - average daily number of hours of sunshine in STC (Standard Test Conditions), $W_{2}$ - deviation from the horizontal plane factor, $W_{3}-$ module temperature factor, $P_{P V}$ - nominal module power, and $E_{a}$ - the electrical efficiency of the photovoltaic solar system.

Losses of the system are given as:

$$
S=S_{1} \cdot S_{2} \cdot S_{3}
$$

where: $S_{1}$-coefficient including losses from the storage device and the voltage drops occurring on the lines (these losses should be assumed to be $6 \%), S_{2}$ - electric to kinetic energy conversion of the flywheel (since electromechanical storage is characterized by high efficiency, we can assume that the average loss is $10 \%$ ), $S_{3}$ - the losses generated by variable insolation and temperature differences (based on the datasheets, we may assume that this value is about $10 \%$ ).

Then, the calculated nominal module power is given as:

$$
P_{P V}=\frac{U}{W_{1} \cdot W_{2} \cdot W_{3} \cdot S}
$$

where: $U$ - daily energy consumption, usually ranging from 1.7 up to $3.5 \mathrm{~kW} /$ day for an average household.

These calculations should be carried out for different seasons. In summer higher nominal power should be selected. In winter season smaller $W_{1}$ factor should be applied. Solar PV systems generate large excess of energy in the summer season, and this excess energy can be discharged to the grid.

The $I-V$ characteristics of $\mathrm{PV}$ are important properties during design of the photovoltaic energy system. In particular, the $I-V$ model of the PV cell is described by:

$$
V_{P V}=\ln \left(\frac{I-I_{P V}}{I_{\text {sat }}}+1\right) \frac{K T}{q}
$$

where: $V_{P V}$ and $I_{P V}$ are photovoltaic operating voltage and current respectively, $I$ and $I_{\text {sat }}$ are the short-circuit and saturation currents, $K$ - the Boltzmann constant, and $T$ is absolute temperature. In the case of a PV array, the total voltage and current are $V_{\text {array }}=N_{s} V_{P V}$ and $I_{\text {array }}=N_{P} I_{P V}$, where $N_{s}$ and $N_{P}$ are the number of series and parallel PV cells respectively. In our case, the characteristics of PV power and current vs. voltage are given in Fig. 5 in the section containing PV simulation calculations.

\subsection{Flywheel integration with pv array photovoltaic solar system}

The proposed household photovoltaic solar system consists of 10 PV panels connected in series with a total electric power of $2.5 \mathrm{~kW}$ and output voltage of $240 \mathrm{~V}$. The photovoltaic solar system and energy storage flywheel interconnection is given in Fig. 1.

Solar panels are connected in series configuration for easier installation, and in the absence of complicated wiring, with less components.

The PV-flywheel installation requires the use of energy converters. Commercial converters adjusted to PV systems (for e.g. Sunny Boy 1300TL) are used. The basic parameters of the converter are: 600 $\mathrm{V}$ maximum input voltage and $180-260 \mathrm{~V}$ rated voltage. The final 


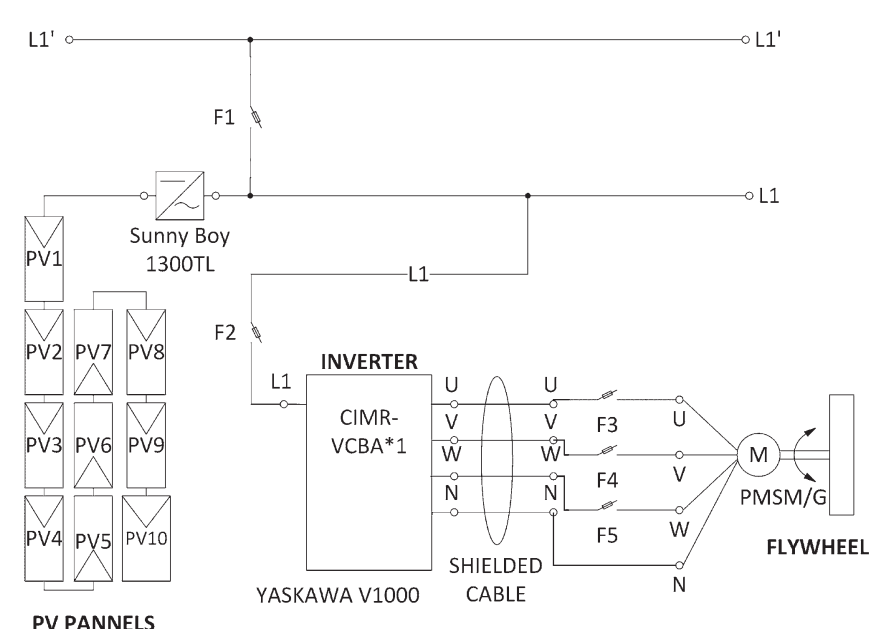

Fig. 1. Power system interconnection

element required for integration of the photovoltaic solar system with the flywheel is an inverter (for e.g. Yaskawa V1000 CIMR-VCBA*1). This inverter is fitted with a built-in control system that allows for motor control (to put it simply, the inverter controls the "charging" process of the flywheel).

\section{AMB flywheel}

Flywheel is the electromechanical energy storage device where storage energy is in the form of kinetic energy. This energy is stored using a flywheel coupled to the electrical machine. Stored energy depends on rotational speed. In order to provide flywheel high rotational speed operation the robustness of the control system is essential. The AMB system identification with disturbance observer-based control is one of common approach $[15,16]$. In embodiments of the AMB flywheel the electric machine works alternately both as a generator and as a motor. The use of rotating mass requires precise control (loss of control of the moving object may cause a serious crash). Authorial AMB flywheel configuration is presented in Fig. 2.

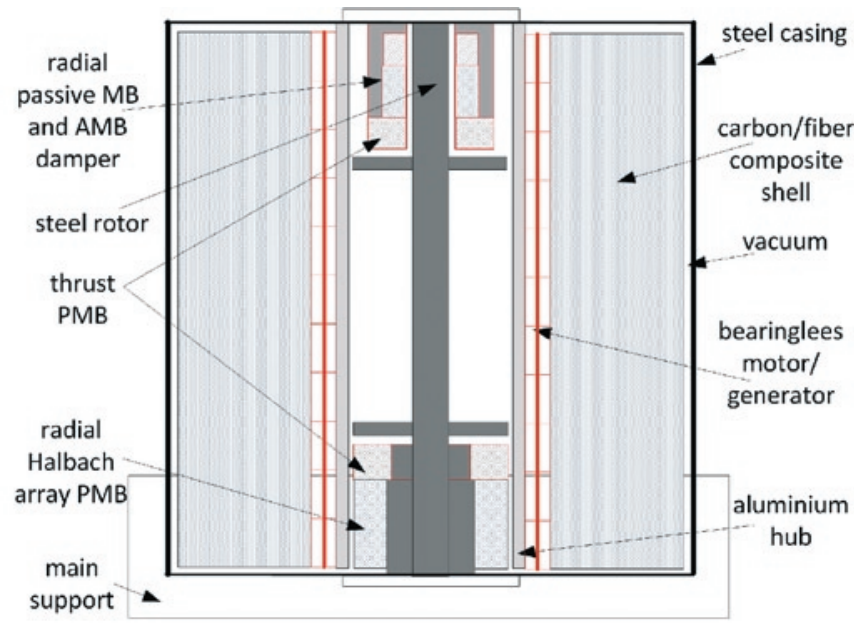

Fig. 2. AMB flywheel configuration as electromechanical energy storage device

The flywheel configuration (Fig. 2) consists of the coreless synchronous motor/generator attached to the high-strength aluminium cylinder rotor supported by hybrid magnetic bearings. Technologies of the Halbach arrays based solid-magnets supports combinations with the active magnetic dampers are used as the energy saving suspension rotor system. The main rotor with motor drive and generator are connected with the composite shell. The bearingless motor in the middle of the shaft provides efficient damping of first bending mode of the rotor. Flywheel's composite shell rotor along with the motor/ generator unit are assumed to be placed into a sealed vacuum chamber, which provides serious problem with heat transfer, produced by rotor losses [20]. The main parameters of the flywheel prototype given for two different shell material variants (see Table 1) are collected and presented in Table 2 .

\subsection{Flywheel design}

The flywheel shell composite material data are collected and presented in Table 1. The advanced composite materials were selected to reduce cost as much as possible and achieve desired performances. During performed simulations, two variants of proposed materials were considered. In both cases, the most important factor was resistance against to stress, deformation of the material, radial displacement, and the rotor strength for wide range of rotational speeds. Particularly, the composite material properties for the both considered variants A and B can be found in datasheets.

Table 1. Summary of different variants of materials for composite rotor

\begin{tabular}{||c|c|c||}
\hline carbon fibre & variant A & variant B \\
\hline fiberglass & type ECR & $\begin{array}{c}\text { impregnated with } \\
\text { resin (CFRP) }\end{array}$ \\
\hline aluminium & $6060-\mathrm{T} 6 ; 7020$ & type S \\
\hline steel & E590K2-T6; 7075-T6 1.4034 & E590K2; 1.4122 \\
\hline POM & $\mathrm{C}$ & $\mathrm{H}$ \\
\hline magnet & neodymium sintered & neodymium tied W4 \\
\hline
\end{tabular}

Table 2. Summary of the results of calculations for various variants of composite rotor

\begin{tabular}{|c|c|c|c|c|}
\hline & \multicolumn{2}{|c|}{ variant $A$} & \multicolumn{2}{|c|}{ variant $B$} \\
\hline mass $[\mathrm{kg}]$ & \multicolumn{2}{|c|}{25.56} & \multicolumn{2}{|c|}{24.01} \\
\hline volume $\left[\mathrm{m}^{3}\right]$ & \multicolumn{2}{|c|}{0.01} & \multicolumn{2}{|c|}{0.01} \\
\hline density $\left[\mathrm{kg} / \mathrm{m}^{3}\right]$ & \multicolumn{2}{|c|}{2496.20} & \multicolumn{2}{|c|}{2344.67} \\
\hline outer radius [mm] & \multicolumn{2}{|c|}{136} & \multicolumn{2}{|c|}{136} \\
\hline inner radius [mm] & \multicolumn{2}{|c|}{84} & \multicolumn{2}{|c|}{84} \\
\hline height [mm] & \multicolumn{2}{|c|}{256} & \multicolumn{2}{|c|}{256} \\
\hline $\begin{array}{c}\text { moment of inertia } \\
{\left[\mathrm{kg} \cdot \mathrm{m}^{2}\right]}\end{array}$ & \multicolumn{2}{|c|}{0.29} & \multicolumn{2}{|c|}{0.27} \\
\hline rotation speed [r/min] & 15000 & 30000 & 15000 & 30000 \\
\hline linear speed $[\mathrm{m} / \mathrm{s}]$ & 213.52 & 427.04 & 213.52 & 427.04 \\
\hline $\begin{array}{l}\text { the angular velocity } \\
{[\mathrm{rad} / \mathrm{s}]}\end{array}$ & 1570 & 3140 & 1570 & 3140 \\
\hline $\begin{array}{c}\text { angular acceleration } \\
{\left[\mathrm{rad} / \mathrm{s}^{2}\right]}\end{array}$ & 26.17 & 52.33 & 26.17 & 52.33 \\
\hline torque $[\mathrm{Nm}]$ & 7.68 & 15.35 & 7.21 & 14.42 \\
\hline power $[\mathrm{KW}]$ & 12.06 & 48.2 & 11.32 & 45.3 \\
\hline kinetic energy [MJ] & 0.36 & 1.46 & 0.34 & 1.36 \\
\hline
\end{tabular}


a)

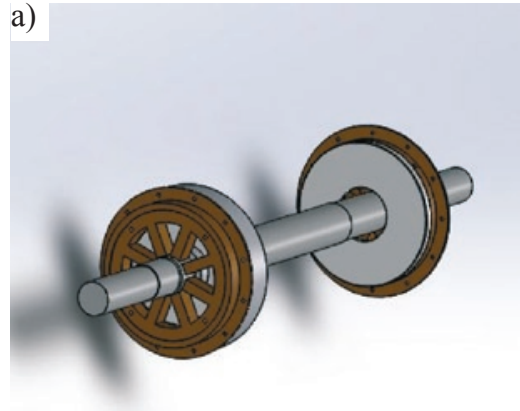

b)

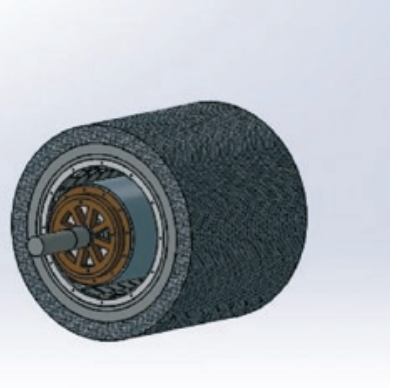

Moreover, this model also allows to determine the photovoltaic panel's parameters (Fig. 4). The main parameters were chosen based on the PV datasheets. The PV simulation model enables to change default parameter for more suitable by the user (userdefine).

The PV model also allows conducting a preliminary study of the whole photovoltaic solar system. For example, this preliminary study includes current and power of PV system due to voltage and temperature change. These results are presented in Fig. 5, where given relations between voltage vs power, and voltage vs current provide useful information about PV system performances.

Another analysis according to PV parameter design is given

Fig. 3. SolidWorks models: a) AMB rotor, b) composite shell flywheel
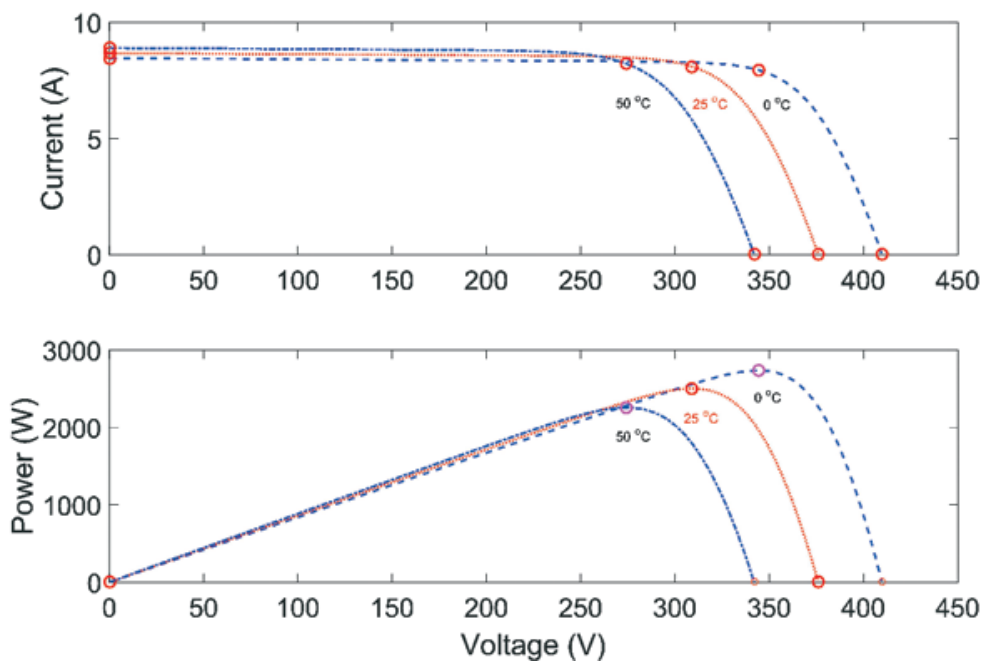

Fig. 5. Preliminary study of $P V$-array
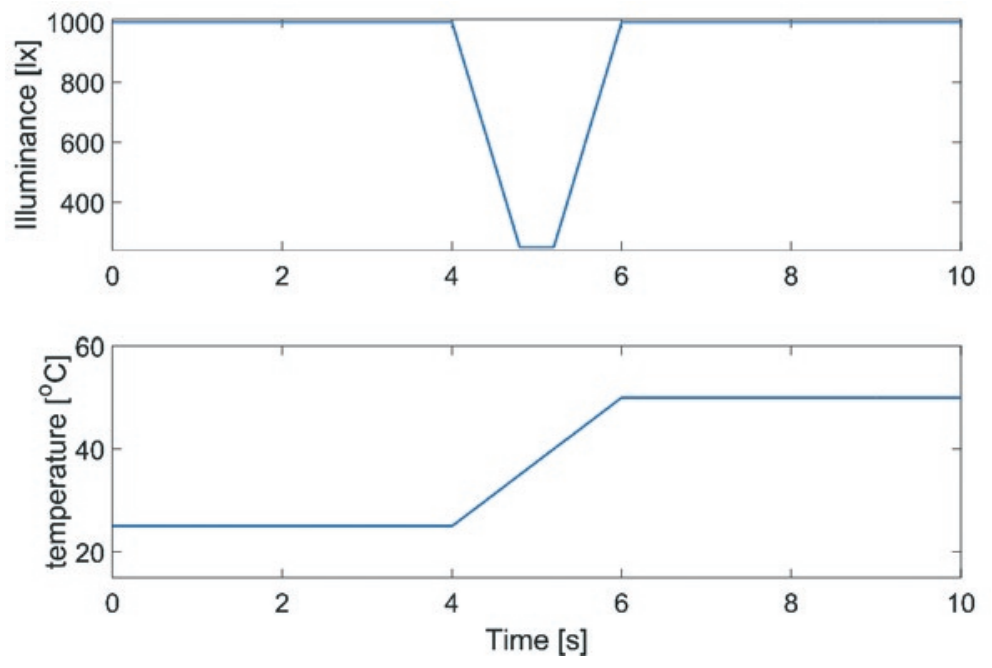

Fig. 6. Designed PV array input signals

\begin{tabular}{|c|c|}
\hline Module: User-defined & - \\
\hline \multicolumn{2}{|c|}{$\square$ Plot I-V and P-V characteristics when a module is selected } \\
\hline Maximum Power (W) & Cells per module (Ncell) \\
\hline 250.29 & 60 \\
\hline Open circuit voltage $\operatorname{Voc}(\mathrm{V})$ & Short-circuit current Isc (A) \\
\hline 37.6 & 8.68 \\
\hline Voltoge at maximum power point $V \mathrm{mp}(\mathrm{V})$ & Current at maximum power point Imp (A) \\
\hline 30.9 & 8.10 \\
\hline Temperature coefficient of Voc (\%/deg.C) & Temperature coefficient of Isc (\%/deg.C) \\
\hline-0.36099 & 0.102 \\
\hline
\end{tabular}

Fig. 4. PV-array model block settings 


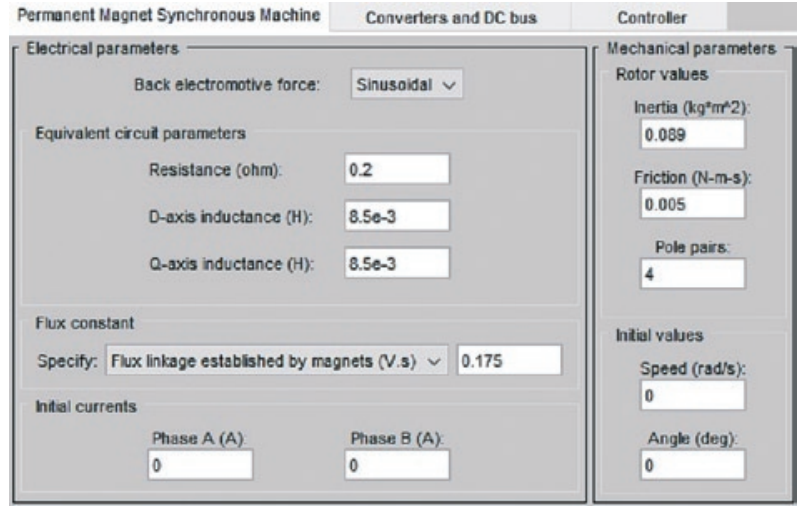

Fig. 7. Dialog window with motor configuration

connections with the flywheel core parameters (i.e. moment of inertia, angular speed, etc.). Simulink/Simscape library was used to design dynamic model of the electric motor/generator. However, this motor/ generator model should be fully compatible with other system components. Particularly, the model contains control system which enables the bypass control logic inverter. The model block of PM synchronous motor drive (with major parametrization presented in Fig. 7) gives the ability to configure the motor parts as well as allows to configure the control system. PM synchronous motor drive includes the ability to work as generator.

The motor/generator dynamics are given as result of following governing equations:

$$
\begin{gathered}
\frac{d}{d t} i_{d}=\frac{1}{L_{d}} V_{d}-\frac{R}{L_{d}} i_{d}+\frac{L_{q}}{L_{d}} p \omega_{m} i_{q} \\
\frac{d}{d t} i_{q}=\frac{1}{L_{q}} V_{q}-\frac{R}{L_{q}} i_{q}-\frac{L_{d}}{L_{q}} p \omega_{m} i_{d}-\frac{\lambda p \omega_{m}}{L_{q}} \\
T_{e}=1.5 p\left[\lambda i_{q}+\left(L_{d}-L_{q}\right) i_{d} i_{q}\right]
\end{gathered}
$$

where: - inductances in $q$ and $d$ axes respectively, - resistance of the stator windings, - currents in $q$ and $d$ axes, - voltages in $q$ and $d$ axes, - angular velocity of the rotor, - amplitude of the flux inducted by the permanent magnets of the rotor in the stator phases, - number of pole pairs, - electromagnetic torque.

The model of the entire system composed of the motor/generator dynamics Eqs. (5-7), all mentioned components and signal blocks al-

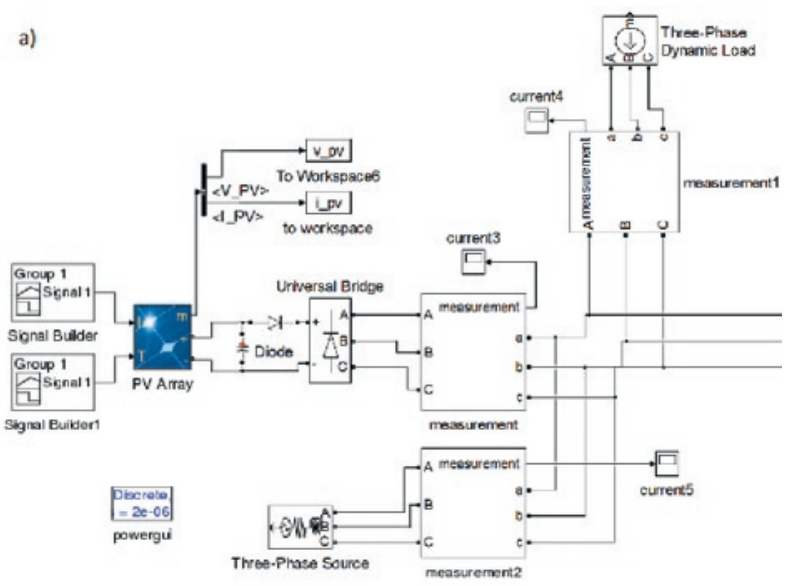

Fig. 8. Simscape model of PV-flywheel storage system: a) photovoltaic system

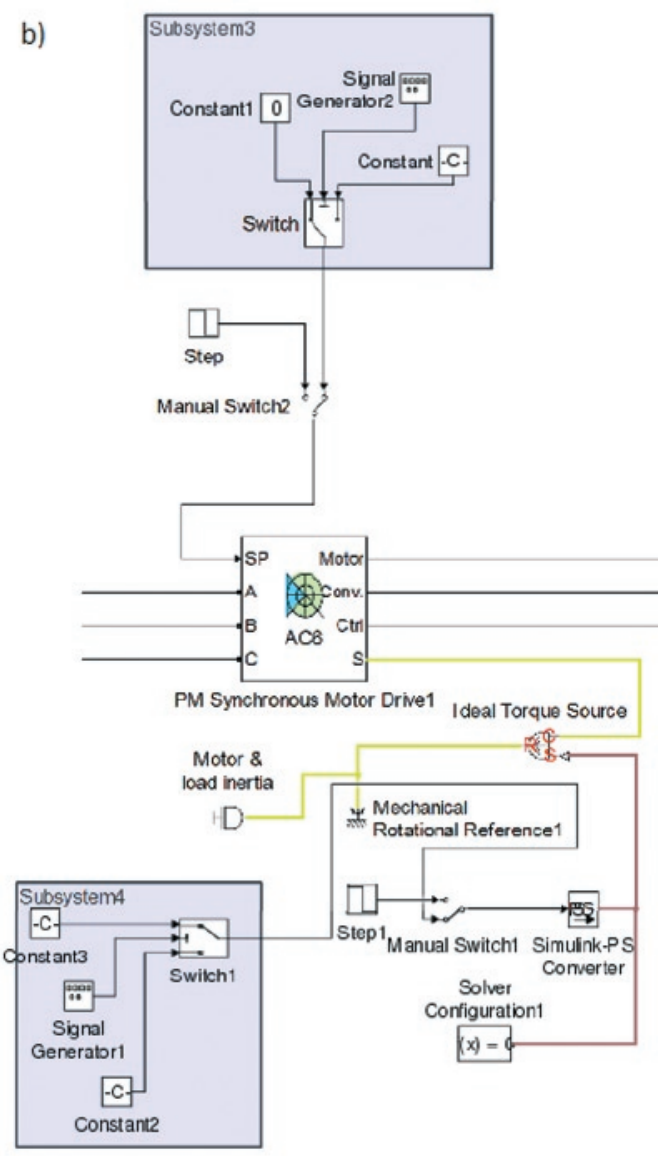

Fig. 8. Simscape model of PV-flywheel storage system: b) PM synchronous motor/generator

low to provide control system simulation. In this simulation the reference input values such as illumination and additional measurement blocks are used to analyse the correctness of operation of the system.

The whole simulation model is presented in Fig. 8, and total amount of elements is divided into two subsystems: photovoltaic model (Fig. 8a) and PM synchronous motor/generator (Fig. 8b). Main parts of the PV model are: PV array, system diodes and universal bridges, and as well as designed models of electric signals measurements. The outputs of the photovoltaic solar system (Fig. 8a) are connected to the inputs of the PM motor (Fig. 8b). The model of motor/ generator includes both electric and mechanical signals measurements and control as torque, rotational speed, etc.

\subsection{Simulation results}

Simulation of the PV-flywheel system should be performed for two time different periods. The short period about $10 \mathrm{sec}$ and long period representing a complete cycle of operation. Due to the long-time simulation and large amount of computer memory needed to analyse the data received during of the simulation is limited to $120 \mathrm{sec}$, where $5 \mathrm{sec}$ for each represents a time unit $(120 / 5=24$ hours as a day/night cycle). During the simulation mode, the motor/generator is charged regularly every $10 \mathrm{sec}$, in order to investigate effects of charging and discharging of the system. The obtained results for long-time simulations as system outputs: torque, rotational speed and currents, are presented in Fig. 9.

As shown in Fig. 9, visible changes in the timing of positive to negative values indicate charging/discharging modes of the motor/ generator operations. These modes provide significant drops in flywheel speed. 

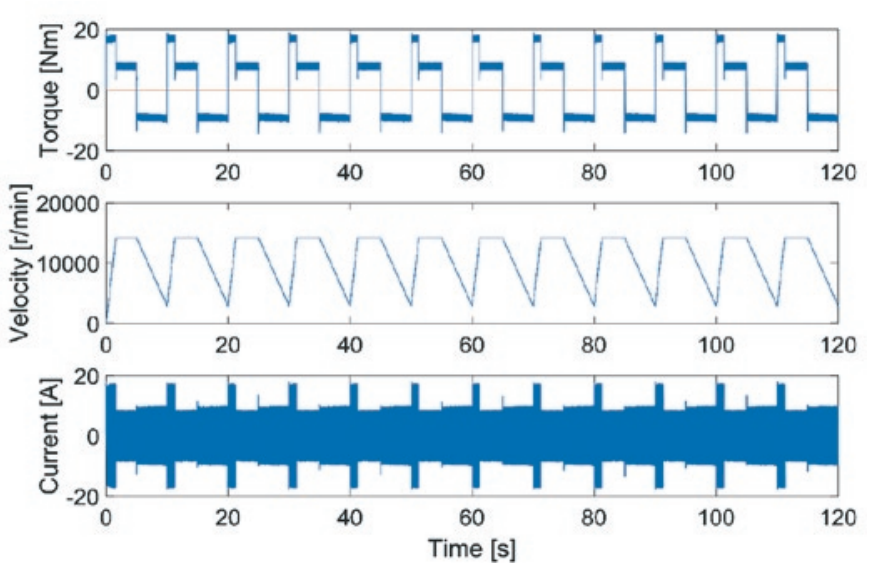

Fig. 9. Graph obtained by long-time simulation with charging and discharging of the PV-flywheel

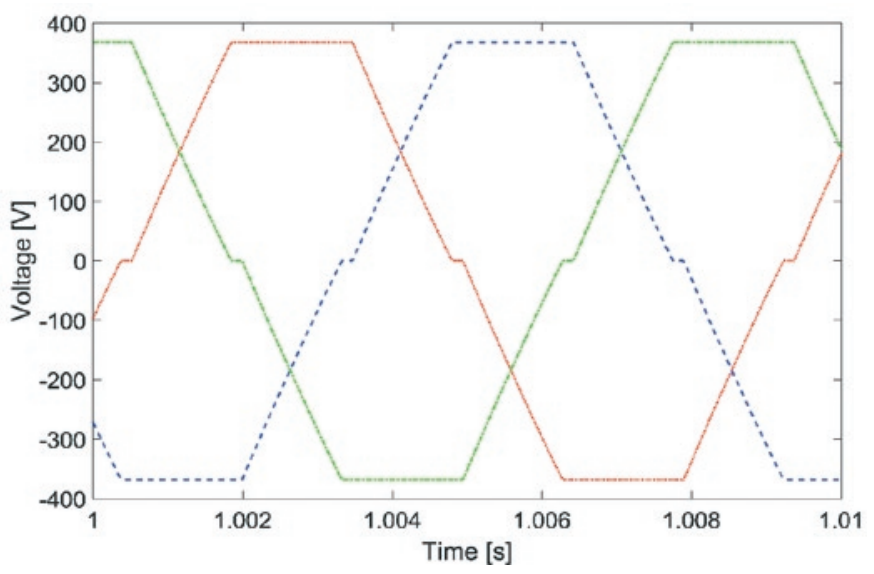

Fig. 10. Voltage waves generated by the photovoltaic panels at zoom

a)

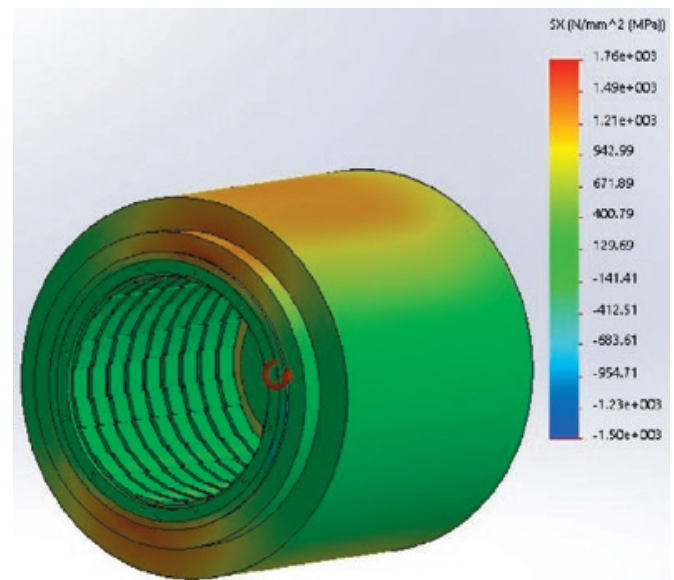

b)

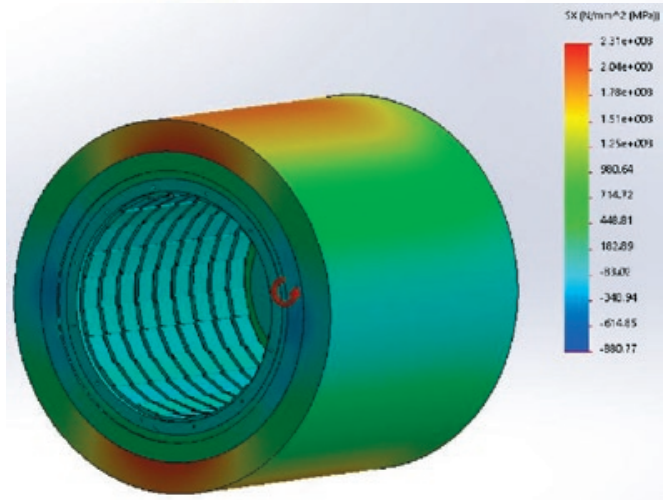

Fig. 11. SolidWorks results for normal stress in $X$ axis: a) material $A, b$ ) material B
The current time responses (Fig. 9) prove that motor/generator operation is stable at the acceleration moments of the flywheel. In the simulation model the PV-flywheel is connected simultaneously to the power grid. Therefore, during the simulation of the photovoltaic panels operation is not possible to see any loses due to changes in light intensity. The PV-array generated output voltage waves for fixed time-window is presented in Fig. 10.

\subsection{Structural calculations of flywheel shell}

In this section, the shell structural calculations were carried out for the material variants A and B using SolidWorks. The radial stress results for maximum rotational speed $60000 \mathrm{rpm}$ are given in Fig. 11.

Figure 12 presents the SolidWorks cross section view of normal stress distribution in $\mathrm{X}$ axis. Based on obtained results given in Fig. 11 and Fig. 12, one can conclude, that in case of material A the maximum stress value is much less compared with material $\mathrm{B}$. The maximum stress values are obtained for the flywheel rotational speed limit and equals $1760 \mathrm{MPa}$ and $2310 \mathrm{MPa}$ for shell material sets A and B respectively. Based on the stress distribution (Fig. 11 and 12) we can predict how much each shell of material set-ups A and B will expand in the radial direction.

The simulation calculations given in Fig. 11 show also that the variant $\mathrm{A}$ is a better option than $\mathrm{B}$. The maximum value of stress for

a)

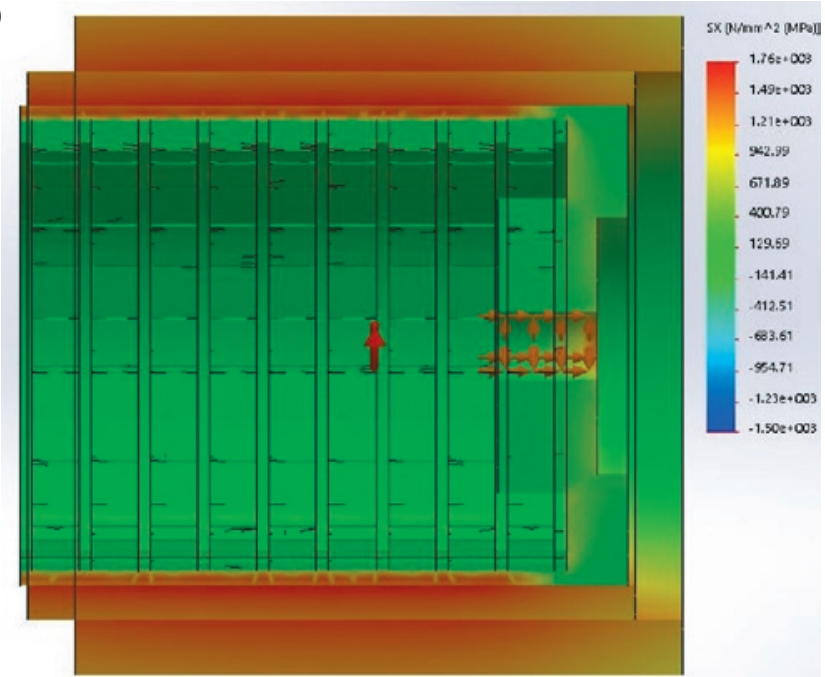

b)

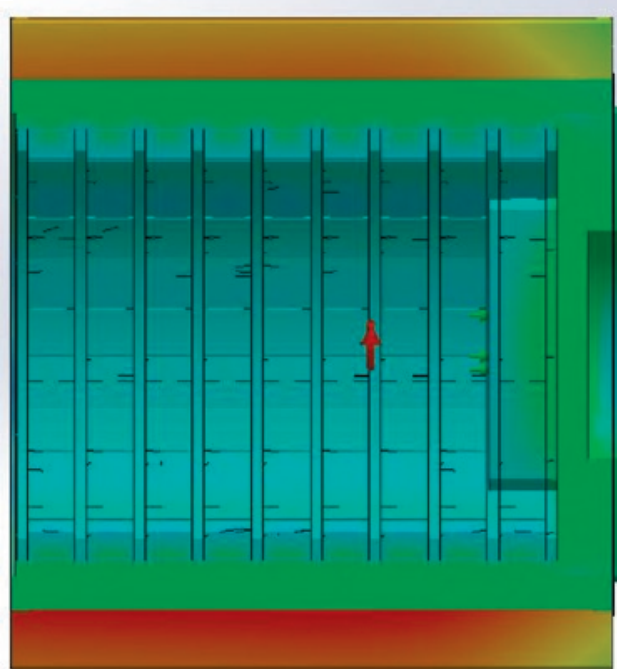

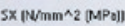

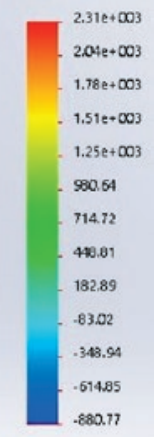

Fig. 12. SolidWorks cross section view of normal stress distribution in X axis: a) material $A$, b) material $B$ 


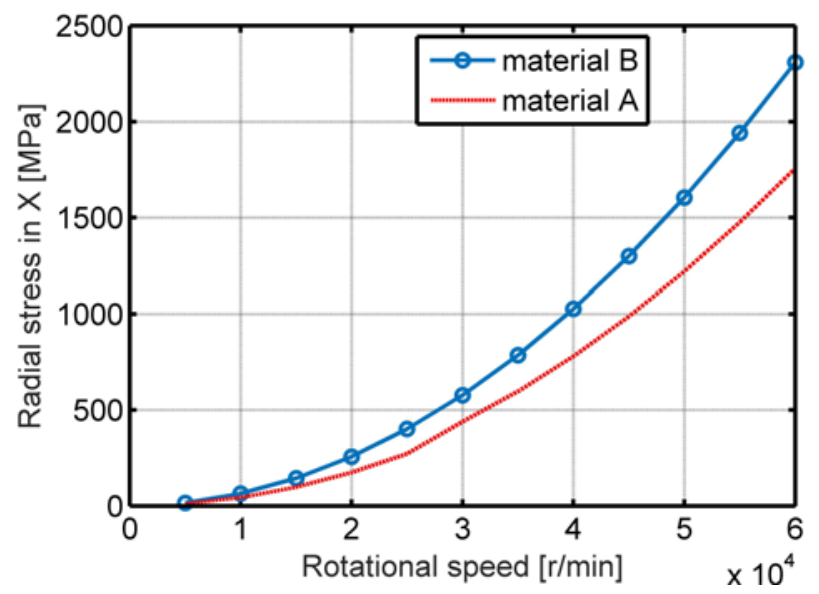

Fig. 13. Radial stress vs rotational speed in the $X$ axis

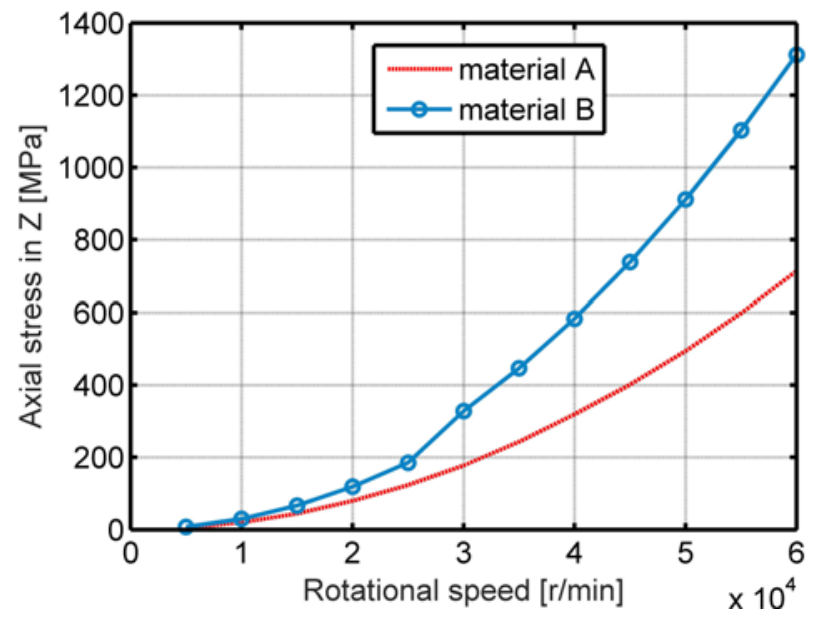

Fig. 14. Axial stress vs rotational speed in the $Z$ axis

material B is higher, and their scope is larger compared with material A.

Next, simulation results are given according to radial stress versus rotational speed (Fig. 13 and Fig. 14).

In addition, after exceeding $25000 \mathrm{r} / \mathrm{min}$ there is a sudden increase in the value of stress, and the flywheel variant A is deformed, while material set-up B remains the same, see Fig. 12a.. This is caused by lower ratio of tensile strength of the materials used in the embodiment A. The simulation show good cooperation between the photovoltaic system and electromechanical uninterruptable power supply.

\section{Experimental investigations}

In this section the AMB flywheel pre-prototype and its experimental results are given according to energy storage investigations. The proposed AMB flywheel is designed and fabricated during the research grant [18].

The flywheel energy storage system (FESS) is designed to run in vacuum and is supported on low-energy controlled active magnetic bearings (AMBs). The total storage energy capacity is approx. $5 \mathrm{MJ}$ which is achieved at the maximum rotational speed equal to 20000 rpm. Total mass of the rotor with the composite shell equal to 150 $\mathrm{kg}$. Two integrated synchronous ( 3 pole pairs and 3 phases) motors/ generators of total $100 \mathrm{~kW}$ power density are performed to operate the flywheel. These motor/generators' cores consists of lamination sheets and permanent magnets mounted on outer rotor. Motor/generators are controlled by electronic inverters using the FPGA controllers. The fly-
Table 3. Parameters of the AMBs

\begin{tabular}{||l|c|c||}
\hline \multicolumn{1}{|c|}{ parameter } & radial AMBs & axial AMB \\
\hline nominal width of air gap & $0.4 \mathrm{~mm}$ & $0.7 \mathrm{~mm}$ \\
\hline bias current & $5 \mathrm{~A}$ & $5 \mathrm{~A}$ \\
\hline maximum current & $10 \mathrm{~A}$ & $10 \mathrm{~A}$ \\
\hline number of coils & 8 & 2 \\
\hline displacement stiffness & $2.6 \mathrm{e} 6 \mathrm{~N} / \mathrm{m}$ & $9.1 \mathrm{e} 6 \mathrm{~N} / \mathrm{m}$ \\
\hline current stiffness & $208 \mathrm{~N} / \mathrm{A}$ & $1.2 \mathrm{e} 3 \mathrm{~N} / \mathrm{A}$ \\
\hline
\end{tabular}

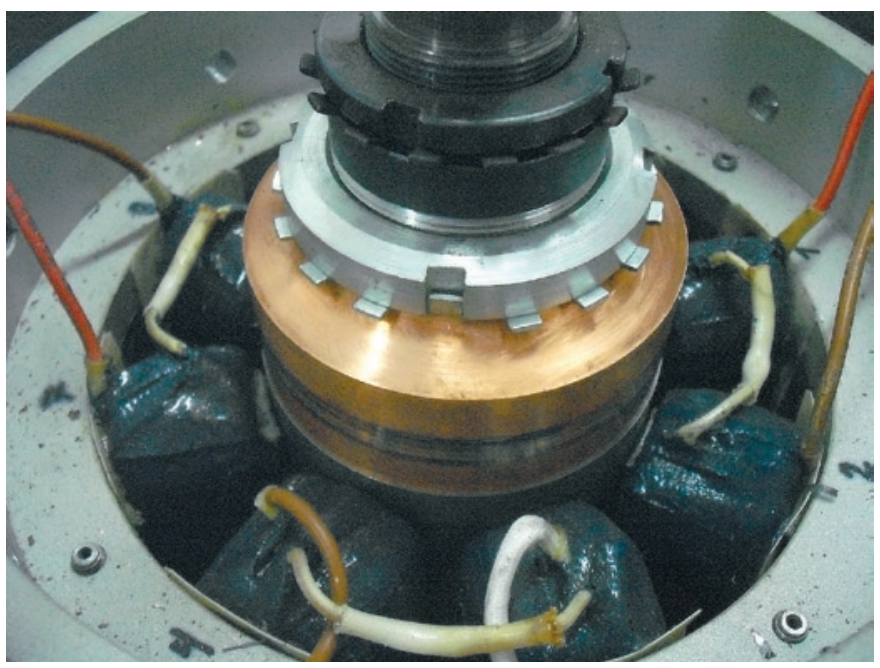

Fig. 15. Radial AMB of flywheel pre-prototype

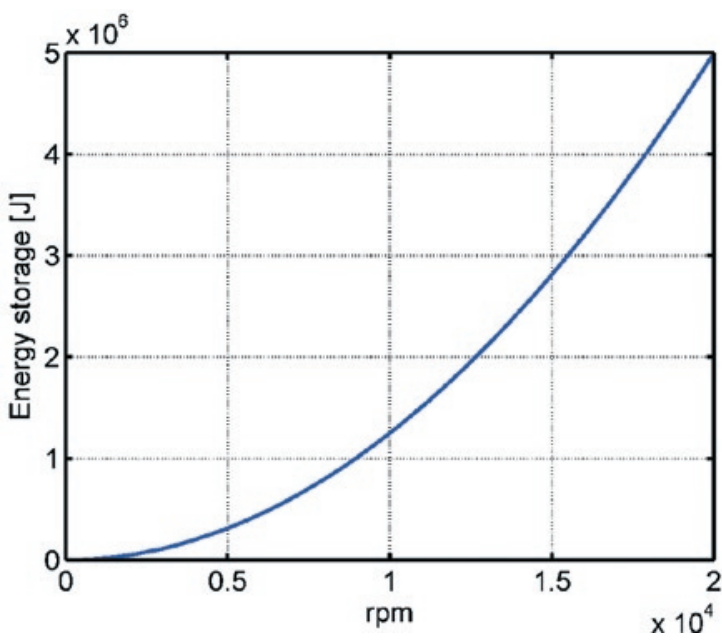

Fig. 16. Energy storage vs flywheel rotational speed range

wheel ratio of the moments of inertia $I_{z} / I_{x}$ equal to $2.28 / 5.75 \mathrm{kgm}^{2}$.

The position control of the $5 \mathrm{DOF}$ (degree of freedom) flywheel is realized by active magnetic bearings in the closed-loop configuration. The low bias-current PD control algorithm with anti-wind up filter is realized. Each of the radial magnetic bearing has 8 electromagnets which are connected to 4 pairs in serial configuration. The magnetic bearings parameters are presented in Table 3 .

The radial AMB of pre-prototype flywheel is given in Fig. 15. The flywheel rotor radial and axial displacements are measured by using 5 eddy-current proximity sensors. The axial bearing (thrust bearing) carriers the weight of the rotor. The radial and axial AMBs are supplied by controlled 10-chanells current PWM amplifiers. The maximal current of the AMB is equal to $10 \mathrm{~A}$. The flywheel-rotor position digital control system is realized in the real time. The control algorithm was 


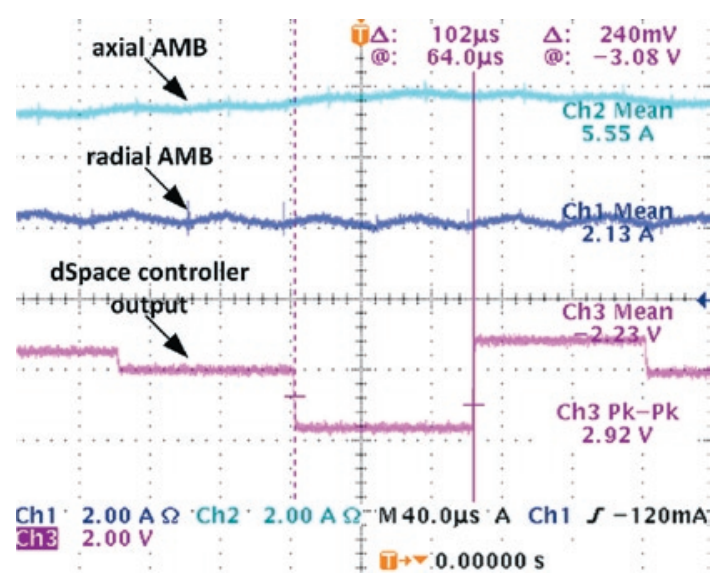

Fig. 17. AMB currents during the flywheel stand-alone

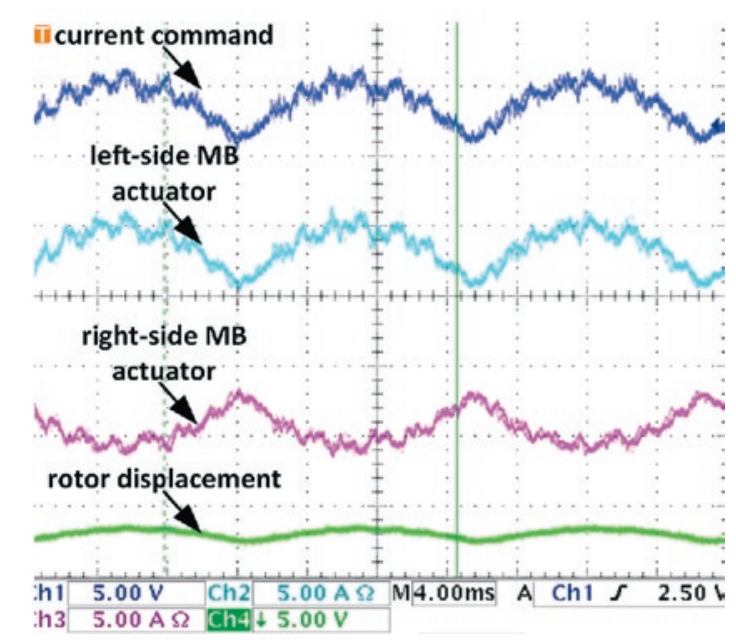

Fig. 18. AMB currents during the flywheel operation at $5300 \mathrm{rpm}$

implemented in digital signal processor (DSP) dSpace. The sampling frequency of the AMBs controllers equal to $10 \mathrm{kHz}$. For more details of AMB flywheel configuration please refers to [11, 12, 18].
For given flywheel mass and moment of inertia, the calculated total energy storage characteristic is given in Fig. 16.

A stable levitation of the FESS rotor was achieved successfully. The measured results of total AMB currents and control command signal are shown in Fig. 17. The mean value of total current supplied to the radial AMBs is about $2 \mathrm{~A}$, where thrust $\mathrm{AMB}$ operates at $5.55 \mathrm{~A}$.

Next results are given for flywheel operation at angular speed of 5 $300 \mathrm{rpm}$. The measured currents in one radial AMB bearing are given in Fig. 18. Also, Fig. 18 presents the current command and flywheelrotor displacement signals. In this case, AMB output currents oscillate around the bias current with the absolute amplitude up to $2.5 \mathrm{~A}$. The obtained currents waves are caused by the flywheel-rotor unbalance. However, in spite of rotor unbalance and disturbances caused by the flywheel energy charging and discharging, the stable flywheel operation is achieved successfully. Thus, measured total consumed power during the AMB flywheel operation is below $0.4 \mathrm{~kW}$.

\section{Conclusions}

In this paper, a PV-flywheel integration system for household purposes has been designed and investigated. Photovoltaic systems suffer from the memory effect, which significantly increases the cost of exploitating such systems. This report has shown that the use of alternative magazines, such as an electromechanical flywheel, significantly reduces operating costs, proving that solutions of this kind are advantageous, and eliminates the memory effect occurring in the common energy reserve. Due to smooth cooperation of electromechanical flywheels and photovoltaic systems, integration of these devices is not a major problem. Integration of the photovoltaic system is possible for each type of uninterruptable power supply; however, in some cases it may be unprofitable. Surroundings of photovoltaic panels, such as tall buildings or trees, were not taken into account during designing of the installation, but they can affect the performance of the actual system.

In order to obtain an efficient system for household purposes with high energy densities and high energy power, the combination of a composite flywheel integrated with a photovoltaic system is required. Designing of this system includes: PV parameter calculations, design and strength computations of the flywheel, and integration.

\section{Acknowledgment}

This work is supported with University Work no S/WM/1/2016 of Department of Automatic Control and Robotics, Bialystok University of Technology also supported with Polish Ministry of Science and Higher Education (MNiSW) and by the Academy of Finland 270012 and 273489 and by Academy of Lithuania.

\section{References}

1. Abbezzot C., Tran T., Poggi P., Serre-Combe P., Perrin M. and Muselli M., Using a flywheel associated to PV power plant in order to increase the integration of PV into island electrical grid, International Conference on Renewable Energies and Power Quality (ICREPQ'13,) Bilbao (Spain), 20-22 March, 2013.

2. Abrahamsson J., Hedlund M., Kamf T. and Bernhoff H., High-speed kinetic energy buffer: optimization of composite shell and magnetic bearings, IEEE Trans. Ind. Electron., 2014; 61(6): 3012-3021, http://dx.doi.org/10.1109/TIE.2013.2259782.

3. Cavallaro C., Musumeci S., Santonocito C. and Pappalardo M., Smart photovoltaic UPS system for domestic appliances, Proc. of IEEEICCEP 09, 9-11 June 2009, Capri, 699-704, http://dx.doi.org/10.1109/iccep.2009.5211952.

4. Daryl R.B. and William D.C., Flywheel energy storage: an alternative for batteries in UPS systems, Energy Engineering: Journal of the association of Energy Engineering, 2005; 102(5): 7-26.

5. De Andrade R., Stephan R.M. and Sotelo G.G., Third generation of flywheels: a promising substitute to batteries, Eletronica de Potencia, 2008; 3, 171-176.

6. Giaconia G.C., Fiscelli G., et all., Integration of distributed on site control actions via combined photovoltaic and solar panels system, Clean Electrical Power, 2009 International Conference on, 9-11 June 2009, 171-177.

7. Kamf T., High speed flywheel design: using advanced composite materials, M.S. thesis, Div. Elect., Uppsala Univ., Uppsala, Sweden, 2012.

8. Kan H.P., Chau K.T. and Cheng M., Development of a doubly salient permanent magnet motor flywheel energy storage for building integrated photovoltaic systems, Proc. of the 16th Applied Power Electronics Conference, 4-8 March 2001, Anaheim, CA, 314-320, http://dx.doi. org/10.1109/apec.2001.911666.

9. Mohd A., Ortjohann E., Schmelter A., Hamsic N. and Morton D., Challenges in integrating distributed energy storage systems into future smart grid, Proc. IEEE Int. Symp. Ind. Electron., 2008; 1627-1632, http://dx.doi.org/10.1109/isie.2008.4676896. 
10. Molina M.G., Distributed energy storage systems for applications in future smart grids, Transmission and Distribution: Latin America Conference and Exposition (T\&D-LA), 2012 Sixth IEEE/PES, 3-5 Sept. 2012, 1-7.

11. Mystkowski A., Energy saving robust control of active magnetic bearings in flywheel, Acta Mechanica et Automatica, 2012; 6, no 3(21): 72-76.

12. Mystkowski A. and Rowinski R., Construction and control of AMBs high speed flywheel, Archive of Mechanical Engineering, 2011; 58(1): 79-89, http://dx.doi.org/10.2478/v10180-011-0005-7.

13. Nagorny A., Dravid N., Jansen R. and Kenny B., Design aspects of a high speed permanent magnet synchronous motor/generator for flywheel applications, in Proc. IEEE International Conference on Electric Machines and Drives, May 2005, 635-641, http://dx.doi.org/10.1109/ iemdc.2005.195790.

14. Navarro G., Torres J., Moreno-Torres P. and Blanco M., Technology description and characterization of a low-cost flywheel for energy management in microgrids, Power Electronics and Applications (EPE'15 ECCE-Europe), 2015 17th European Conference on, 8-10 Sept. 2015, Geneva, 1-10.

15. Noshadi A., Shi J., Lee W.S., Shi P. and Kalam A., System identification and robust control of multi-input multi-output active magnetic bearing systems, IEEE Transactions on Control Systems Technology, 2016; 24 (4), 1227-1239, http://dx.doi.org/10.1109/TCST.2015.2480009.

16. Noshadi A., Shi J., Lee W.S., Shi P. and Kalam A., Robust control of an active magnetic bearing system using Ho and disturbance observerbased control, Journal of Vibration and Control, 2015, http://dx.doi.org/10.1177/1077546315602421.

17. Pena-Alzola R., Sebastian R., Quesada J. and Colmenar A., Review of flywheel based energy storage systems, in Proc. POWERENG'11, May 2011, 1-6, http://dx.doi.org/10.1109/powereng.2011.6036455.

18. Pirog S. and Gosiewski Z., eds., Electromechanical, high-speed, stationary energy store, project no PBZ-KBN-109/T-10/2004, supported by Polish Ministry of Science and Higher Education, 2010; in Polish, 1-306.

19. Smith S., Sen P., and Kroposki B., Advancement of energy storage devices and applications in electrical power system, in Proc. IEEE Power and Energy Society General Meeting, July 2008, 1-8, http://dx.doi.org/10.1109/pes.2008.4596436.

20. Sokolov M.A, Jastrzebski R.P., Saarakkala S.E., Hinkkanen M., Mystkowski A., Pyrhönen J., Pyrhönen O., Analytical method for design and thermal evaluation of a long-term flywheel energy storage system, The 23rd International Symposium on Power Electronics, Electrical Drives, Automation and Motion, 22-24 June 2016, Anacapri, Capri Island, Italy, pp. 270-275. (DOI: 10.1109/SPEEDAM.2016.7525911)

21. Tant J., Geth F., Six D., Tant P. and Driesen J., Multiobjective battery storage to improve PV integration in residential distribution grids, IEEE Trans. Sustain. Energy, 2013; 4(1): 182-191, http://dx.doi.org/10.1109/TSTE.2012.2211387.

22. Vazquez S., Lukic S., Galvan E., Franquelo L., Carrasco J., Leon J., and Hilton J., Recent advances on energy storage systems, in Proc. IEEE 37th IECON, Nov. 2011, 4636-4640.

23. Yali Y., Yuanxi W. and Feng S., The latest development of the motor/generator for the flywheel energy storage system, in Proc. MEC'11, Aug 2011, 1228-1232, http://dx.doi.org/10.1109/mec.2011.6025689.

24. Zondag H.A., Van Helden W.G.J., PV-thermal domestic systems, Proc. of 3rd World Conference on Photovoltaic Energy Conversion, May 11-18, 2003 Osaka, Japan, 2000-2003.

\section{Michal SMOLINSKI \\ Tomasz PERKOWSKI \\ Arkadiusz MYSTKOWSKI}

Automatic Control and Robotics, Mechanical Engineering

Department, Bialystok University of Technology

ul. Wiejska 45A, 15-351 Bialystok, Poland

\section{Egidijus DRAGAŠIUS \\ Darius EIDUKYNAS}

Faculty of Mechanical Engineering and Design

Kaunas University of Technology

Studentu str., 56-321 Kaunas, Lithuania

\section{Rafal P. JASTRZEBSKI}

LUT Energy, Lappeenranta University of Technology

Skinnarilankatu 34, 53850 Lappeenranta, Finland

E-mails: michal.smolinski@onet.eu, tomperk2@gmail.com, a.mystkowski@pb.edu.pl, egidijus.dragasius@ktu.lt, darius.eidukynas@ktu.lt, Rafal.Jastrzebski@lut.fi 